\title{
MENGATASI KESULITAN BELAJAR DENGAN PENDEKATAN PSIKOLOGI KOGNITIF
}

\author{
Oleh: Ridwan Idris*
}

\begin{abstract}
The profession of teaching is not always easy, as it needs respective knowledge and skill. The responsibility of teachers is not only to transfer their knowledge to their students, but most importantly is to help them solve learning difficulties. Students coming to schools bring different problems as they are from different background. Some go to school with their personal problems, and some with family problems. The teachers, therefore, should be close to their students and know their individual learning difficulties, and help them how to learn effectively.
\end{abstract}

KEYWORDS: Kesulitan belajar, siswa, guru, psikologi kognitif

PROSES pembelajaran di sekolah tidaklah mudah untuk diaplikasikan, guru sering dihadapkan dengan bermacam-macam masalah termasuk di dalamnya dalam menentukan teknik, metode dan media yang sesuai dengan karakter siswa. Persoalannya adalah di sekolah berbagai macam pula karakterisktik siswa. Sejumlah siswa mungkin dapat menempuh kegiatan belajarnya secara lancar dan berhasil tanpa mengalami kesulitan, tetapi di sisi lain tidak sedikit pula siswa yang justru dalam belajarnya mengalami berbagai kesulitan.

Sebagai seorang guru yang sehari-hari mengajar di sekolah, tentunya tidak jarang harus menangani anak-anak yang mengalami kesulitan dalam belajar. Anak-anak sepertinya sulit sekali menerima materi pelajaran, baik pelajaran membaca, menulis, serta berhitung. Hal ini terkadang membuat guru menjadi frustasi memikirkan bagaimana menghadapi anak-anak seperti ini. Demikian juga para orang tua yang memiliki anak-anak yang memiliki kesulitan dalam belajar. Harapan agar anak mereka menjadi anak yang pandai, mendapatkan nilai yang baik di sekolah menambah kesedihan mereka ketika melihat kenyataan bahwa anak-anak mereka kesulitan dalam belajar.

*Peraih Magister Pendidikan dalam bidang manajemen pendidikan dari Universitas Negeri Makassar ini adalah kandidat doktor pada Program Studi Manajemen Pendidikan Universitas Negeri Jakarta. Saat ini ia menjadi dosen tetap Fakultas Tarbiyah dan Keguruan UIN Alauddin Makassar. 
Kesulitan belajar siswa ditunjukkan oleh adanya hambatan-hambatan tertentu untuk mencapai hasil belajar, dan dapat bersifat psikologis, sosiologis, maupun fisiologis, sehingga pada akhirnya dapat menyebabkan prestasi belajar yang dicapainya berada di bawah semestinya. ${ }^{1}$

Kesulitan belajar bila tidak ditangani dengan baik dan benar akan menimbulkan berbagai bentuk gangguan emosional (psikiatrik) yang akan berdampak buruk bagi perkembangan kualitas hidupnya di kemudian hari. Idealnya anak dengan kesulitan belajar dapat ditangani dengan baik dan dapat mengatasi masalah yang menimpanya. Namun demikian, sering tampak perlakuan yang diterima anak yang mengalami kesulitan belajar dari orang tua dan guru tidaklah sesuai yang diharapkan. Anak kesulitan belajar sering dicap sebagai anak yang bodoh, tolol, ataupun gagal. Hal inilah yang menjadi penghambat bagi anak dengan kesulitan belajar.

Kepekaan orang tua, guru di sekolah serta masyarakat sekitar sangat membantu dalam mendeteksinya, sehingga anak dengan kesulitan belajar dapat memperoleh penanganan dari tenaga profesional sedini dan seoptimal mungkin. Fenomena ini kemudian menjadi perhatian para ilmuan yang tertarik dengan masalah kesulitan belajar. Keuntungannya ialah, mereka mencoba menemukan metode-metode yang dapat digunakan untuk membantu anak-anak yang mengalami kesulitan belajar tersebut tetap dapat belajar dan mencapai apa yang diharapkan guru dan orang tua.

Dalam tulisan ini akan dibahas mengenai pengertian kesulitan belajar, gejala-gejala kesulitan belajar, faktor-faktor kesulitan belajar, diagnosis kesulitan belajar dan pemecahan masalahnya.

\section{DEFINISI KESULITAN BELAJAR}

Menurut National Institute of Health, USA kesulitan belajar adalah hambatan/gangguan belajar pada anak dan remaja yang ditandai oleh adanya kesenjangan yang signifikan antara taraf intelegensia dan kemampuan akademik yang seharusnya dicapai. Lebih lanjut dijelaskan bahwa kesulitan belajar kemungkinan disebabkan oleh gangguan di dalam sistem saraf pusat otak (gangguan neurobiologis) yang dapat menimbulkan gangguan perkembangan seperti gangguan perkembangan bicara, membaca, menulis, pemahaman dan berhitung. ${ }^{2}$

Selain definisi tersebut di atas, menurut Sudrajat kesulitan belajar siswa mencakup pengertian yang luas, di antaranya: (a) learning disorder; b) learning disfunction; (c) underachiever; (d) slow learner, dan (e) learning disabilities. ${ }^{3}$ Di bawah ini akan diuraikan dari masing-masing pengertian tersebut. 


\section{Learning Disorder}

Learning disorder atau kekacauan belajar adalah keadaan dimana proses belajar seseorang terganggu karena timbulnya respons yang bertentangan. Pada dasarnya, yang mengalami kekacauan belajar, potensi dasarnya tidak dirugikan, akan tetapi belajarnya terganggu atau terhambat oleh adanya respons-respons yang bertentangan, sehingga hasil belajar yang dicapainya lebih rendah dari potensi yang dimilikinya. Contoh: siswa yang sudah terbiasa dengan olah raga keras seperti karate, tinju dan sejenisnya, mungkin akan mengalami kesulitan dalam belajar menari yang menuntut gerakan lemah-gemulai.

\section{Learning Disfunction}

Learning disfunction merupakan gejala dimana proses belajar yang dilakukan siswa tidak berfungsi dengan baik, meskipun sebenarnya siswa tersebut tidak menunjukkan adanya subnormalitas mental, gangguan alat dria, atau gangguan psikologis lainnya. Contoh: siswa yang yang memiliki postur tubuh yang tinggi atletis dan sangat cocok menjadi atlet bola volley, namun karena tidak pernah dilatih bermain bola volley, maka dia tidak dapat menguasai permainan volley dengan baik.

\section{Under Achiever}

Under achiever mengacu kepada siswa yang sesungguhnya memiliki tingkat potensi intelektual yang tergolong di atas normal, tetapi prestasi belajarnya tergolong rendah. Contoh: siswa yang telah dites kecerdasannya dan menunjukkan tingkat kecerdasan tergolong sangat unggul (IQ = 130 140), namun prestasi belajarnya biasa-biasa saja atau malah sangat rendah.

\section{Slow Learner}

Slow learner atau lambat belajar adalah siswa yang lambat dalam proses belajar, sehingga ia membutuhkan waktu yang lebih lama dibandingkan sekelompok siswa lain yang memiliki taraf potensi intelektual yang sama.

\section{Learning Disabilities}

Learning disabilities atau ketidakmampuan belajar mengacu pada gejala dimana siswa tidak mampu belajar atau menghindari belajar, sehingga hasil belajar di bawah potensi intelektualnya.

Dari pernyataan di atas, dapat disimpulkan bahwa kesulitan belajar adalah suatu kesulitan yang berdampak serius pada kemampuan anak didik dalam menerima pelajarannya. Kesulitan tersebut berasal dari luar 
(eksternal) dan dari dalam (internal) anak didik. Yang terpenting dari hal ini adalah bagaimana guru, orang tua dan masyarakat sekitar untuk dapat mengatasinya. Dengan demikian perlu kiranya untuk dapat mengetahui faktor-faktor apa yang melatarbelakangi sehingga kesulitan ini bisa terjadi. Sehingga dengan pengetahuan yang ada guru, orang tua dan masyarakat lain dapat mengambil tindakan yang efektif.

\section{FAKTOR-FAKTOR KESULITAN BELAJAR}

Fenomena kesulitan belajar dapat dilihat dari menurunnya penampilan akademik atau prestasi belajarnya. Selain itu, kesulitan belajar dapat dilihat dari adanya atau munculnya perilaku yang tidak biasa (misbehavior) siswa seperti suka berteriak di kelas, mengganggu teman, berkelahi, sering tidak masuk sekolah serta sering minggat dari sekolah. Syah mengidentifikasi faktor-faktor penyebab kesulitan belajar sebagai berikut:

- Faktor intern siswa, yakni hal-hal atau keadaan-keadaan yang muncul dari dalam diri siswa sendiri.

- Faktor ekstern siswa, yakni hal-hal atau keadaan-keadaan yang datang dari luar diri siswa. ${ }^{4}$

Kedua faktor ini meliputi aneka ragam hal dan keadaan yang antara lain tersebut di bawah ini.

\section{Faktor Internal Siswa}

Faktor internal siswa meliputi gangguan atau kekurangmampuan psiko-fisik siswa, yakni:

- Yang bersifat kognitif (ranah cipta), antara lain seperti rendahnya kapasitas intelektual/inteligensi siswa;

- Yang bersifat afektif (ranah rasa), antara lain seperti labilnya emosi dan sikap.

- Yang bersifat psikomotor (ranah karsa), antara lain seperti terganggunya alat-alat indera penglihat dan pendengar (mata dan telinga).

\section{Faktor Eksternal Siswa}

Faktor eksternal siswa meliputi semua situasi dan kondisi lingkungan sekitar yang tidak mendukung aktivitas belajar siswa. Faktor ini dapat dibagi tiga macam.

- Lingkungan keluarga, contohnya; ketidakharmonisan hubungan antara ayah dengan ibu, dan rendahnya kehidupan ekonomi keluarga.

- Lingkungan perkampungan/masyarakat, contohnya; wilayah perkampungan kumuh (slum area), dan teman sepermainan (peer group) yang nakal. 
- Lingkungan sekolah, contohnya; kondisi dan letak gedung sekolah yang buruk seperti dekat pasar, kondisi guru serta alat-alat belajar yang berkualitas rendah.

Selain faktor-faktor yang bersifat umum di atas, ada pula faktorfaktor lain yang juga menimbulkan kesulitan belajar siswa. Di antara faktor-faktor yang dapat dipandang sebagai faktor khusus ini ialah sindrom psikologis berupa learning disability (ketidakmampuan belajar). Menurut Reber, sindrom yang berarti satuan gejala yang muncul sebagai indikator adanya keabnormalan psikis yang menimbulkan kesulitan belajar, yaitu:

- Disleksia (dyslexia), yakni ketidakmampuan belajar membaca.

- Disgrafia (dysgraphia), yakni ketidakmampuan belajar menulis.

- Diskalkulia (dyscalculia), yakni ketidakmampuan belajar matematika. ${ }^{5}$

Akan tetapi, siswa yang mengalami sindorm-sindrom di atas secara umum sebenarnya memiliki potensi IQ yang normal bahkan di antaranya ada yang memiliki kecerdasan di atas rata-rata. Oleh karena itu, kesulitan belajar siswa yang menderita sindrom-sindrom tadi mungkin hanya disebabkan oleh adanya minimal brain dysfunction, yaitu gangguan ringan pada otak.

Menurut Sternberg, otak sangat berperan penting terhadap pemrosesan kognitif siswa karena otak adalah organ dalam tubuh kita yang mengontrol langsung pikiran, emosi dan motivasi kita. Dengan demikian, gangguan sedikit saja terhadap otak akan mengganggu sistem saraf yang lain dan pada akhirnya siswa mungkin tidak termotivasi dalam belajar. ${ }^{6}$

Lebih lanjut Sternberg menjelaskan, ada sejumlah gangguan otak yang bisa menyebabkan kesulitan belajar pada anak didik, di antaranya:

- Stroke yang terjadi akibat aliran darah ke otak mengalami hambatan. Orang-orang yang mengalami stroke biasanya menimbulkan hilangnya fungsi-fungsi kognitif. Bentuk hilangnya fungsi-fungsi ini bergantung pada area otak mana yang dipengaruhi stroke. Bentuk-bentuk tersebut meliputi kelumpuhan, rasa sakit, mati rasa, tidak dapat berbicara, tidak mampu memahami bahasa, gangguan di dalam proses berpikir, tidak mampu mengontrol gerakan bagian-bagian tubuh tertentu atau simtomsimtom yang lain.

- Tumor otak dapat mempengaruhi fungsi kognitif dengan cara yang sangat serius. Tumor bisa tumbuh entah pada materi abu-abu atau materi putih otak.

- Luka pada kepala bisa diakibatkan oleh berbagai macam faktor seperti kecelakaan kendaraan, kontak dengan benda keras dan terkena peluru. ${ }^{7}$ 
Singkatnya, kerusakan otak bisa diakibatkan dari beragam sebab, dan hanya beberapa sebab yang diuraikan dalam tulisan ini. Ketika kerusakan otak terjadi, siswa harus segera ditangani oleh seorang spesialis medis sedini mungkin dan psikolog rehabilitasi untuk membantu siswa kembali pada tingkatan fungsi psikologisnya yang optimal.

Masalah kesulitan belajar ini, tentunya disebabkan oleh berbagai faktor. Untuk memberikan suatu bantuan kepada anak yang mengalami kesulitan belajar, tentunya kita harus mengetahui terlebih dahulu faktor apa yang menjadi penyebab munculnya masalah kesulitan belajar. Lebih luas Ahmadi menyebutkan faktor-faktor penyebab kesulitan belajar ke dalam dua golongan, yaitu:

- Faktor intern (faktor dari dalam diri anak itu sendiri ) yang meliputi: 1). Faktor fisiologi, adalah faktor fisik dari anak itu sendiri. seorang anak yang sedang sakit, tentunya akan mengalami kelemahan secara fisik, sehingga proses menerima pelajaran, memahami pelajaran menjadi tidak sempurna. Selain sakit faktor fisiologis yang perlu kita perhatikan karena dapat menjadi penyebab munculnya masalah kesulitan belajar adalah cacat tubuh, yang dapat kita bagi lagi menjadi cacat tubuh yang ringan seperti kurang pendengaran, kurang penglihatan, serta gangguan gerak, serta cacat tubuh yang tetap (serius) seperti buta, tuli, bisu, dan lain sebagainya. 2). Faktor psikologis adalah berbagai hal yang berkenaan dengan berbagai perilaku yang ada dibutuhkan dalam belajar. Sebagaimana diketahui bahwa belajar tentunya memerlukan sebuah kesiapan, ketenangan, rasa aman. Selain itu yang juga termasuk dalam faktor psikologis ini adalah intelligensi yang dimiliki oleh anak. Anak yang memiliki IQ cerdas (110-140), atau genius (lebih dari 140) memiliki potensi untuk memahami pelajaran dengan cepat. Sedangkan anak-anak yang tergolong sedang (90-110) tentunya tidak terlalu mengalami masalah walaupun juga pencapaiannya tidak terlalu tinggi. Sedangkan anak yang memiliki IQ dibawah 90 atau bahkan dibawah 60 tentunya memiliki potensi mengalami kesulitan dalam masalah belajar. Untuk itu, maka orang tua, serta guru perlu mengetahui tingkat IQ yang dimiliki anak atau anak didiknya. Selain IQ, faktor psikologis yang dapat menjadi penyebab munculnya masalah kesulitan belajar adalah bakat, minat, motivasi, kondisi kesehatan mental anak, dan juga tipe anak dalam belajar.

- Faktor ekstern (faktor dari luar anak) meliputi; 1). Faktor-faktor sosial yaitu faktor-faktor seperti cara mendidik anak oleh orang tua mereka di rumah. Anak-anak yang tidak mendapatkan perhatian yang cukup tentunya akan berbeda dengan anak-anak yang cukup mendapatkan 
perhatian, atau anak yang terlalu diberikan perhatian. Selain itu juga bagimana hubungan orang tua dengan anak, apakah harmonis, atau jarang bertemu, atau bahkan terpisah. Hal ini tentunya juga memberikan pengaruh pada kebiasaan belajar anak. 2). Faktor-faktor non-sosial Faktor-faktor non-sosial yang dapat menjadi penyebab munculnya masalah kesulitan belajar adalah faktor guru di sekolah, kemudian alatalat pembelajaran, kondisi tempat belajar, serta kurikulum. ${ }^{8}$

Dengan memperhatikan faktor-faktor penyebab dari kesulitan belajar, guru, orang tua dan pakar pendidikan dapat segera mengambil tindakan dalam mengatasi kesulitan tersebut. Dengan demikian diharapkan dapat menjamin siswa lebih baik lagi pada masa yang akan datang.

\section{GEJALA-GEJALA KESULITAN BELAJAR}

Siswa sering mengalami gejala-gejala yang tidak mestinya dan di luar kebiasaan. Dalam hal ini biasanya guru atau orang tua menganggap siswa tersebut mungkin malas atau bodoh dan tidak dipedulikan bahkan akan diasingkan. Keadaan ini tidak akan menyelesaikan masalah bahkan akan menambah parah masalah yang muncul. Oleh karena itu, guru perlu mendeteksi gejala-gejala yang ada untuk dapat memberikan solusi. Menurut Sudrajat kesulitan belajar dapat dimanifestasikan dalam perilakunya, baik aspek psikomotorik, kognitif, konatif maupun afektif. Beberapa perilaku yang merupakan manifestasi gejala kesulitan belajar, antara lain:

- Menunjukkan hasil belajar yang rendah di bawah rata-rata nilai yang dicapai oleh kelompoknya atau di bawah potensi yang dimilikinya.

- Hasil yang dicapai tidak seimbang dengan usaha yang telah dilakukan. Mungkin ada siswa yang sudah berusaha giat belajar, tapi nilai yang diperolehnya selalu rendah

- Lambat dalam melakukan tugas-tugas kegiatan belajarnya dan selalu tertinggal dari kawan-kawannya dari waktu yang disediakan.

- Menunjukkan sikap-sikap yang tidak wajar, seperti: acuh tak acuh, menentang, berpura-pura, dusta dan sebagainya.

- Menunjukkan perilaku yang berkelainan, seperti membolos, datang terlambat, tidak mengerjakan pekerjaan rumah, mengganggu di dalam atau pun di luar kelas, tidak mau mencatat pelajaran, tidak teratur dalam kegiatan belajar, dan sebagainya.

- Menunjukkan gejala emosional yang kurang wajar, seperti : pemurung, mudah tersinggung, pemarah, tidak atau kurang gembira dalam menghadapi situasi tertentu. Misalnya dalam menghadapi nilai rendah, tidak menunjukkan perasaan sedih atau menyesal, dan sebagainya. ${ }^{9}$

Sementara itu, Burton mengidentifikasi siswa yang diduga mengalami kesulitan belajar, yang ditunjukkan oleh adanya kegagalan siswa 
dalam mencapai tujuan-tujuan belajar. Menurut dia bahwa siswa dikatakan gagal dalam belajar apabila:

- Dalam batas waktu tertentu yang bersangkutan tidak mencapai ukuran tingkat keberhasilan atau tingkat penguasaan materi (mastery level) minimal dalam pelajaran tertentu yang telah ditetapkan oleh guru (criterion reference).

- Tidak dapat mengerjakan atau mencapai prestasi semestinya, dilihat berdasarkan ukuran tingkat kemampuan, bakat, atau kecerdasan yang dimilikinya. Siswa ini dapat digolongkan ke dalam under achiever.

- Tidak berhasil tingkat penguasaan materi (mastery level) yang diperlukan sebagai prasyarat bagi kelanjutan tingkat pelajaran berikutnya. Siswa ini dapat digolongkan ke dalam slow learner atau belum matang (immature), sehingga harus menjadi pengulang (repeater). ${ }^{10}$

Untuk dapat menetapkan gejala kesulitan belajar dan menandai siswa yang mengalami kesulitan belajar, maka diperlukan kriteria sebagai batas atau patokan, sehingga dengan kriteria ini dapat ditetapkan batas bagi siswa yang dapat diperkirakan mengalami kesulitan belajar.

Lebih lanjut dalam situs yang dikeluarkan oleh Learning Disabilities Association of America menyebutkan bahwa gejala-gejala yang sering timbul bagi anak dengan kesulitan belajar bervariasi dan tergantung pada usia anak.

- Pada usia pra-sekolah

- Keterlambatan berbicara jika dibandingkan dengan anak seusianya

- Adanya kesulitan dalam pengucapan kata

- Kemampuan penguasaan jumlah kata yang minim

- Seringkali tidak mampu menemukan kata yang sesuai untuk suatu kalimat

- Kesulitan untuk mempelajari dan mengenali angka, huruf dan namanama hari

- Mengalami kesulitan dalam menghubungkan kata-kata dalam suatu kalimat

- Kegelisahan yang sangat ekstrim dan mudah teralih perhatiannya

- Kesulitan berinteraksi dengan anak seusianya

- Menunjukkan kesulitan dalam mengikuti suatu petunjuk atau rutinitas tertentu

- Menghindari pekerjaan tertentu seperti menggunting dan menggambar

- Pada usia sekolah

- Daya ingatnya (relatif) kurang baik 
- Sering melakukan kesalahan yang konsisten dalam mengeja dan membaca. Misalnya huruf $\mathrm{d}$ dibaca $\mathrm{b}$, huruf $\mathrm{w}$ dibaca $\mathrm{m}$ dan lain sebagainya.

- Lambat untuk mempelajari hubungan antara huruf dengan bunyi pengucapannya

- Bingung dengan operasionalisasi tanda-tanda dalam pelajaran matematika, misalnya tidak dapat membedakan antara tanda matematika.

- Sulit dalam mempelajari keterampilan baru, terutama yang membutuhkan kemampuan daya ingat.

- Sangat aktif dan tidak mampu menyelesaikan satu tugas atau kegiatan tertentu dengan tuntas.

- Impulsif (bertindak sebelum berpikir).

- Sulit konsentrasi atau perhatiannya mudah teralih

- Sering melakukan pelanggaran baik di sekolah atau di rumah.

- Tidak bertanggung jawab terhadap kewajibannya.

- Tidak mampu merencanakan kegiatan sehari-harinya.

- Problem emosional seperti mengasingkan diri, pemurung, mudah tersinggung atau acuh terhadap lingkungannya.

- Menolak sekolah.

- Mengalami kesulitan dalam mengikuti petunjuk atau rutinitas tertentu.

- Ketidakstabilan dalam menggenggam pensil/pen

- Kesulitan dalam mempelajari pengertian tentang hari dan waktu

- Pada Usia Remaja dan Dewasa

- Membuat kesalahan dalam mengeja berlanjut hingga dewasa.

- Sering menghindar dari tugas membaca dan menulis.

- Kesulitan dalam menyimpulkan suatu bacaan.

- Kesulitan menjawab suatu pertanyaan yang membutuhkan penjelasan lisan dan/atau tulisan.

- Kemampuan daya ingat lemah.

- Kesulitan dalam menyerap konsep yang abstrak.

- Bekerja lamban.

- Bisa kurang perhatian pada hal-hal yang rinci atau bisa juga terlalu fokus kepada hal-hal yang rinci.

- Bisa salah dalam membaca informasi. ${ }^{11}$

Demikian gejala-gejala yang ditemukan pada anak yang mengalami kesulitan belajar. Gejala-gejala yang ada mungkin sangat mendetail tapi tidak sempurna, tetapi dengan melihat gejala-gejala yang ada setelah dilakukan diagnosa maka setiap orang dapat mengambil tindakan. 


\section{MENGATASI KESULITAN BELAJAR}

Sebelum menetapkan alternatif pemecahan masalah kesulitan belajar siswa, guru sangat dianjurkan untuk terlebih dahulu melakukan identifikasi (upaya mengenali gejala dengan cermat) terhadap fenomena yang menunjukkan kemungkinan adanya kesulitan belajar yang melanda siswa tersebut. Upaya seperti ini disebut diagnosis yang bertujuan menetapkan "jenis penyakit" yakni jenis kesulitan belajar siswa.

Dalam melakukan diagnosis diperlukan adanya prosedur yang terdiri atas langkah-langkah tertentu yang diorientasikan pada ditemukannya kesulitan belajar jenis tertentu yang dialami siswa. Prosedur seperti ini dikenal sebagai "diagnostik" kesulitan belajar.

Banyak langkah-langkah diagnostik yang dapat ditempuh guru, antara lain yang cukup terkenal adalah proses Weener dan Senf sebagaimana yang dikutip Syah sebagai berikut:

- Melakukan observasi kelas untuk melihat perilaku menyimpang siswa ketika mengikuti pelajaran.

- Memeriksa penglihatan dan pendengaran siswa khususnya yang diduga mengalami kesulitan belajar.

- Mewancarai orang tua atau wali siswa untuk mengetahui hal ihwal keluarga yang mungkin menimbulkan kesulitan belajar.

- Memberikan tes diagnostik bidang kecakapan tertentu untuk mengetahui hakikat kesulitan belajar yang dialami siswa.

- Memberikan tes kemampuan intelegensia (IQ) khususnya kepada siswa yang diduga mengalami kesulitan belajar. ${ }^{12}$

Secara umum, langkah-langkah tersebut di atas dapat dilakukan dengan mudah oleh guru kecuali langkah ke-5 (tes IQ). Untuk keperluan tes $I Q$, guru dan orang tua siswa dapat berhubungan dengan klinik psikologi. Dalam hal ini, yang sangat perlu dicatat ialah apabila siswa yang mengalami kesulitan belajar itu ber-IQ jauh di bawah normal (tuna grahita), orang tua hendaknya mengirimkan siswa tersebut ke lembaga pendidikan khusus anak-anak tuna grahita, karena lembaga/sekolah biasa tidak menyediakan tenaga pendidik dan kemudahan belajar khusus untuk anak-anak anormal. Selanjutnya, para siswa yang nyata-nyata menunjukkan misbehavior berat seperti perilaku agresif yang berpotensi antisosial atau kecanduan narkotika, harus diperlakukan secara khusus pula, umpamanya dimasukkan ke lembaga pemasyarakatan anak-anak atau ke "pesantren" khusus pecandu narkotika.

Adapun untuk mengatasi kesulitan belajar siswa pengidap sindrom disleksia, disgrafia, dan diskalkulia sebagaimana yang telah diuraikan 
sebelumnya, guru dan orang tua sangat dianjurkan untuk memanfaatkan support teacher (guru pendukung). Guru khusus ini biasanya bertugas menangani para siswa pengidap sindrom-sindrom tadi di samping melakukan remedial teaching (pengajaran perbaikan).

Sayangnya di sekolah-sekolah di Indonesia tidak seperti di kebanyakan sekolah negara-negara maju, belum menyediakan guru-guru pendukung. Namun, untuk mengatasi kesulitan karena tidak adanya support teacher itu orang tua siswa dapat berhubungan dengan biro konsultasi psikologi dan pendidikan yang biasanya terdapat pada fakultas psikologi dan fakultas keguruan yang terkemuka di kota-kota besar tertentu.

Banyak alternatif yang dapat diambil guru dalam mengatasi kesulitan belajar siswanya. Akan tetapi, sebelum pilihan tertentu diambil, guru sangat diharapkan untuk terlebih dahulu melakukan beberapa langkah penting sebagaimana yang dikemukakan Syah (2000: 175) sebagai berikut:

- Menganalisa hasil diagnosis, yakni menelaah bagian-bagian masalah dan hubungan antarbagian tersebut untuk memperoleh pengertian yang benar mengenai kesulitan belajar yang dihadapi siswa.

- Mengidentifikasi dan menentukan bidang kecakapan tertentu yang memerlukan perbaikan.

- Menyusun program perbaikan, khususnya program remedial teaching (pengajaran perbaikan).

- Melaksanakan program perbaikan. ${ }^{13}$

\section{Analisis Hasil Diagnosis}

Data dan informasi yang diperoleh guru melalui diagnostik kesulitan belajar tadi perlu dianalisis sedemikian rupa, sehingga jenis kesulitan khusus yang dialami siswa berprestasi rendah itu dapat diketahui secara pasti.

\section{Menentukan Kecakapan Bidang Bermasalah}

Berdasarkan hasil analisis tadi, guru diharapkan dapat menentukan bidang kecakapan tertentu yang dianggap bermasalah dan memerlukan perbaikan. Bidang-bidang kecakapan bermasalah ini dapat dikategorikan menjadi tiga macam;

- Bidang kecakapan bermasalah yang dapat ditangani oleh guru sendiri.

- Bidang kecakapan bermasalah yang dapat ditangani oleh guru dengan bantuan orang tua.

- Bidang kecakapan bermasalah yang tidak dapat ditangani baik oleh guru maupun orang tua.

Bidang kecakapan yang tidak dapat ditangani atau terlalu sulit untuk ditangani baik oleh guru maupun orang tua dapat bersumber dari kasus- 
kasus tuna grahita (lemah mental) dan kecanduan narkotika. Mereka yang termasuk dalam lingkup dua macam kasus yang bermasalah berat ini dipandang tidak berketerampilan (unskilled people). Oleh karenanya, para siswa yang mengalami kedua masalah kesulitan belajar yang berat tersebut tidak hanya memerlukan pendidikan khusus, tetapi juga memerlukan perawatan khusus.

\section{Menyusun Program Perbaikan}

Dalam hal menyusun program pengajaran perbaikan (remedial teaching), sebelumnya guru perlu menetapkan hal-hal sebagai berikut;

- Tujuan pengajaran remedial

- Materi pengajaran remedial

- Metode pengajaran remedial

- Alokasi waktu pengajaran remedial

- Evaluasi kemajuan siswa setelah mengikuti program pengajaran remedial.

\section{Melaksanakan Program Perbaikan}

Kapan dan di mana program pengajaran remedial yang telah dirancang itu dapat dilaksanakan? Pada prinsipnya, program pengajaran remedial itu lebih cepat dilaksanakan tentu saja akan lebih baik. Tempat penyelenggaraannya bisa di mana saja, asal tempat itu memungkinkan siswa memusatkan perhatiannya terhadap proses perbaikan tersebut. Namun patut dipertimbangkan oleh guru pembimbing kemungkinan digunakannya ruang bimbingan dan penyuluhan yang tersedia di sekolah dalam rangka mendayagunakan ruang BP tersebut.

Selanjutnya, untuk memperluas wawasan pengetahuan mengenai alternatif-alternatif kiat pemecahan masalah kesulitan belajar siswa, guru sangat dianjurkan mempelajari buku-buku khusus mengenai bimbingan dan penyuluhan. Selain itu, guru juga dianjurkan untuk mempertimbangkan penggunaan model-model mengajar tertentu yang dianggap sesuai sebagai alternatif lain atau pendukung cara memecahkan masalah kesulitan belajar siswa.

Demikian beberapa hal yang dapat dilakukan untuk mengatasi anak dengan kesulitan belajar. Selain yang di atas, masih banyak cara untuk mengatasi kesulitan belajar, salah satunya yang dikemukakan oleh Wood Cyang khusus membahas anak dengan kesulitan membaca atau disleksia (dyslexia), anak dengan kesulitan belajar menulis atau disgrafia (dysgraphia), dan anak dengan kesulitan belajar matematika atau diskalkulia (dyscalculia). ${ }^{14}$ 


\section{Kesulitan Membaca (Dyslexia)}

Anak yang memiliki keterlambatan kemampuan membaca, mengalami kesulitan dalam mengartikan atau mengenali struktur kata-kata (misalnya huruf atau suara yang seharusnya tidak diucapkan, sisipan, penggantian atau kebalikan) atau memahaminya (misalnya, memahami fakta-fakta dasar, gagasan, utama, urutan peristiwa, atau topik sebuah bacaan). Mereka juga mengalami kesulitan lain seperti cepat melupakan apa yang telah dibacanya.

Sebagian ahli berargumen bahwa kesulitan mengenali bunyi-bunyi bahasa (fonem) merupakan dasar bagi keterlambatan kemampuan membaca. Kemampuan ini penting sekali bagi pemahaman hubungan antara bunyi bahasa dan tulisan yang mewakilinya. Istilah lain yang sering dipergunakan untuk menyebutkan keterlambatan membaca adalah disleksia. Istilah ini sebenarnya merupakan nama bagi salah satu jenis keterlambatan membaca saja. Semasa awal kanak-kanak, seorang anak yang menderita disleksia mengalami kesulitan dalam mempelajari bahasa lisan. Selanjutnya ketika tiba masanya untuk sekolah, anak ini mengalami kesulitan dalam mengenali dan mengeja kata-kata, sehingga pada akhirnya mereka mengalami masalah dalam memahami maknanya.

Disleksia mempengaruhi 5 hingga 10 persen dari semua anak yang ada. Kondisi ini pertama kali diketahui pada abad ke sembilan belas, ketika itu disebut dengan buta huruf (word blindness). Beberapa peneliti menemukan bahwa disleksia cenderung mempengaruhi anak laki-laki lebih besar dibanding anak perempuan. Tanda-tanda disleksia tidak sulit dikenali, bila seorang guru dan orang tua cermat mengamatinya. Sebagai contoh, bila anda menunjukkan sebuah buku yang asing pada seorang anak penderita disleksia, ia mungkin akan mengarang-ngarang cerita berdasarkan gambar yang ia lihat tanpa berdasarkan tulisan isi buku tersebut. Bila anda meminta anak tersebut untuk berfokus pada kata-kata dibuku itu, ia mungkin berusaha untuk mengalihkan permintaan tersebut. Ketika anda menyuruh anak tersebut untuk memperhatikan kata-kata, maka kesulitan membaca pada anak tersebut akan terlihat jelas. Beberapa kesulitan bagi anak-anak penderita disleksia adalah sebagai berikut:

- Membaca dengan sangat lambat dan dengan enggan

- Menyusuri teks pada halaman buku dengan menggunakan jari telunjuk.

- Mengabaikan suku kata, kata-kata, frase, atau bahkan baris teks.

- Menambahkan kata-kata atau frase yang tidak ada dalam teks.

- Membalik urutan huruf atau suku kata dalam sebuah kata.

- Salah dalam melafalkan kata-kata, termasuk kata-kata yang sudah 
dikenal.

- Mengganti satu kata dengan kata lain, meskipun kata yang digantikan tidak mempunyai arti dalam konteksnya.

- Menyusun kata-kata yang tidak mempunyai arti.

- Mengabaikan tanda baca.

\section{Kiat Mengatasi Problem Disleksia}

Cara yang paling sederhana, paling efektif untuk membantu anakanak penderita disleksia belajar membaca dengan mengajar mereka membaca dengan metode phonic. Idealnya anak-anak akan mempelajari phonic di sekolah bersama guru, dan juga meluangkan waktu untuk berlatih phonic di rumah bersama orang tua mereka. Metode phonic ini telah terbukti berpengaruh terhadap peningkatan kemampuan anak dalam membaca. Metode phonic ini merupakan metode yang digunakan untuk mengajarkan anak yang mengalami problem disleksia agar dapat membaca melalui bunyi yang dihasilkan oleh mulut. Metode ini sudah dapat dikemas dalam bentuk yang beraneka ragam, baik buku, maupun software. Bagi orang tua, berikut ini merupakan ide-ide yang dapat membantu anak dengan phonic dan membaca:

\section{Kesulitan Menulis (Dysgraphia)}

Dalam sebuah pelatihan menjadi ahli ilmu kesehatan anak, terdapat seorang ahli ilmu kesehatan yang bernama Stephen yang tidak pernah menulis apapun di atas kertas. Ia menggunakan mesin ketik yang dapat dibawa ke mana-mana (portable) untuk segala sesuatu laporan pasien, catatan singkat. Kemudian diketahui bahwa Stephen memang tidak dapat menulis secara jelas. Seberapapun ia mencoba dengan keras ia tidak dapat menulis apapun dengan jelas, sehingga dia dan orang lain tidak dapat membaca tulisan tangannya.

Apa yang dialami Stephen merupakan problem kesulitan menulis (disgraphia). Tentunya disgraphya ini berbeda dengan tulisan tangan yang jelek. Tulisan tangan yang jelek biasanya tetap dapat terbaca oleh penulisnya, dan juga dilakukan dalam waktu yang relatif sama dengan yang menulis dengan bagus. Akan tetapi, untuk dysgraphia, anak membutuhkan waktu yang lebih lama untuk menulis.

Dalam menulis sesuatu dibutuhkan penglihatan yang cukup jelas, keterampilan motorik halus, pengetahuan tentang bahasa dan ejaan, dan otak untuk mengkoordinasikan ide dengan mata dan tangan untuk menghasilkan tulisan. Jika salah satu elemen tersebut mengalami masalah maka menulis akan menjadi suatu pekerjaan yang sulit atau tidak mungkin dilakukan. 


\section{Kiat Mengatasi Problem Disgrapia}

Untuk mengatasi problem dysgraphia ini, sangatlah baik apabila kita belajar dari sebuah kasus anak yang mengalami dysgraphia. Problem dysgraphia muncul pada Stephen saat sekolah dasar, ia memiliki nilai yang bagus pada masa-masa awal, akan tetapi kemudian nilainya jatuh dan akhirnya guru Stephen di kelas V memanggilnya, dan juga memanggil orang tuanya. Guru tersebut meminta orang tua Stephen untuk mengajari Stephen mengetik pada mesin ketik yang dapat dibawa ke mana-mana (portable). Hasilnya nilai dan prestasi Stephen meningkat secara tajam.

Sebagian ahli merasa bahwa pendekatan yang terbaik untuk dysgraphia adalah dengan jalan mengambil jalan pintas atas problem tersebut, yaitu dengan menggunakan teknologi untuk memberikan kesempatan pada anak mengerjakan pekerjaan sekolah tanpa harus bersusah payah menulis dengan tangannya.

Ada dua bagian dalam pendekatan ini. Anak-anak menulis karena dua alasan: pertama untuk menangkap informasi yang mereka butuhkan untuk belajar (dengan menulis catatan) dan kedua untuk menunjukkan pengetahuan mereka tentang suatu mata pelajaran (tes-tes menulis).

Sebagai ganti menulis dengan tangan, anak-anak dapat: Meminta fotokopi dari catatan-catatan guru atau meminta ijin untuk mengkopi catatan anak lain yang memiliki tulisan tangan yang bagus; mereka dapat mengandalkan teman tersebut dan mengandalkan buku teks untuk belajar. Belajar cara mengetik dan menggunakan laptop/notebook untuk membuat catatan di rumah dan menyelesaikan tugas-tugas sekolah. Menggunakan alat perekam untuk menangkap informasi saat pelajaran. Sebagai ganti menulis jawaban tes dengan tangan, mereka dapat: 1) Melakukan tes secara lisan, 2) mengerjakan tes dengan pilihan ganda, 3) mengerjakan tes-tes yang dibawa pulang (take-home test) atau 4) tes dalam kelas dengan cara mengetik.

Bila strategi-strategi di atas tidak mungkin dilakukan karena beberapa alasan, maka anak-anak penderita dysgraphia harus diijinkan untuk mendapatkan waktu tambahan untuk tes-tes dan ujian tertulis. Keuntungan dari pendekatan ini adalah bahwa pendekatan ini memberikan perbedaan yang segera tampak pada anak. Dari pada mereka harus bersusah payah menguasai suatu keterampilan yang sangat sulit bagi mereka, dan nantinya mungkin akan jarang dibutuhkan ketika beranjak dewasa, mereka dapat berkonsentrasi untuk mempelajari keterampilan lain, dan dapat menunjukkan apa yang mereka ketahui. Hal ini membuat mereka merasa lebih baik berkenaan dengan sekolah dan diri mereka sendiri. 
Tidak ada alasan untuk menyangkal kesempatan bagi seorang anak yang cerdas untuk meraih kesuksesan di sekolah. Selain itu, karena pendidikan sangatlah penting bagi masa depan anak, maka tidak sepadan resiko membiarkan anak menjadi semakin lama semakin frustasi dan menjadi putus asa karena pekerjaan sekolah.

\section{Kesulitan Menghitung (Dyscalculia)}

Berhitung merupakan kemampuan yang digunakan dalam kehidupan sehari-hari, baik ketika membeli sesuatu, membayar rekening listrik, dan lain sebagainya. Tidak diragukan lagi bahwa berhitung merupakan pekerjaan yang kompleks yang di dalamnya melibatkan membaca, menulis, dan keterampilan bahasa lainnya seperti; kemampuan untuk membedakan ukuran-ukuran dan kuantitas relatif dan obyektif, kemampuan untuk mengenali urutan, pola, dan kelompok, ingatan jangka pendek untuk mengingat elemen-elemen dari sebuah soal matematika saat mengerjakan persamaan, kemampuan membedakan ide-ide abstrak, seperti angkaangka negatif, atau sistem angka yang tidak menggunakan basis sepuluh.

Meskipun banyak masalah yang mungkin turut mempengaruhi kemampuan untuk memahami, dan mencapai keberhasilan dalam pelajaran matematika. Istilah dyscalculia, biasanya mengacu pada pada suatu problem khusus dalam menghitung, atau melakukan operasi aritmatika, yaitu penjumlahan, pengurangan, perkalian, dan pembagian. Anak yang mengalami problem dyscalculia merupakan anak yang memiliki masalah pada kemampuan menghitung. Anak tersebut tentunya belum tentu anak yang bodoh dalam hal yang lain, hanya saja ia mengalami masalah dengan kemampuan menghitungnya.

\section{Kiat Mengatasi Anak dengan Dyscalculia}

Seperti halnya problem kesulitan menulis dan membaca, ada dua pendekatan yang dapat dilakukan; Pendekatan yang pertama, yaitu penanganan matematika yang intensif, dapat kita lakukan dengan teknik "individualisasi yang dibantu tim". Pendekatan ini menggunakan pengajaran secara privat dengan teman sebaya (peer tutoring). Pendekatan ini mendasari tekniknya pada pemahaman bahwa kecepatan belajar seorang anak berbeda-beda, sehingga ada anak yang cepat menangkap, dan ada juga yang lama. Teknik ini mendorong anak yang cepat menangkap materi pelajaran agar mengajarkannya pada temannya yang lain yang mengalami problem dyscalculia tersebut.

Pendekatan yang kedua, yaitu jalan pintas, dengan memberikan kalkulator untuk menghitung. Hal ini sederhana karena anak dengan problem 
dyscalculia tidak memiliki masalah dengan kaitan antara angka, akan tetapi lebih kepada menghitung angka-angka tersebut.

Selanjutnya, ada satu bentuk pemecahan masalah kesulitan belajar yang disebut dengan bimbingan belajar. Menurut Sudrajat bimbingan belajar merupakan upaya guru untuk membantu siswa yang mengalami kesulitan dalam belajarnya. ${ }^{15}$ Secara umum, prosedur bimbingan belajar dapat ditempuh melalui langkah-langkah sebagai berikut:

\section{Identifikasi kasus}

Identifikasi kasus merupakan upaya untuk menemukan siswa yang diduga memerlukan layanan bimbingan belajar. Robinson memberikan beberapa pendekatan yang dapat dilakukan untuk mendeteksi siswa yang diduga mebutuhkan layanan bimbingan belajar, yakni:

- Call them approach; melakukan wawancara dengan memanggil semua siswa secara bergiliran sehingga dengan cara ini akan dapat ditemukan siswa yang benar-benar membutuhkan layanan bimbingan.

- Maintain good relationship; menciptakan hubungan yang baik, penuh keakraban sehingga tidak terjadi jurang pemisah antara guru dengan siswa. Hal ini dapat dilaksanakan melalui berbagai cara yang tidak hanya terbatas pada hubungan kegiatan belajar mengajar saja, misalnya melalui kegiatan ekstra kurikuler, rekreasi dan situasi-situasi informal lainnya.

- Developing a desire for counseling; menciptakan suasana yang menimbulkan ke arah penyadaran siswa akan masalah yang dihadapinya. Misalnya dengan cara mendiskusikan dengan siswa yang bersangkutan tentang hasil dari suatu tes, seperti tes inteligensi, tes bakat, dan hasil pengukuran lainnya untuk dianalisis bersama serta diupayakan berbagai tindak lanjutnya.

- Melakukan analisis terhadap hasil belajar siswa, dengan cara ini bisa diketahui tingkat dan jenis kesulitan atau kegagalan belajar yang dihadapi siswa.

- Melakukan analisis sosiometris, dengan cara ini dapat ditemukan siswa yang diduga mengalami kesulitan penyesuaian sosial. ${ }^{16}$

\section{Identifikasi Masalah}

Langkah ini merupakan upaya untuk memahami jenis, karakteristik kesulitan atau masalah yang dihadapi siswa. Dalam konteks Proses Belajar Mengajar, permasalahan siswa dapat berkenaan dengan aspek: (a) substansial-material; (b) struktural-fungsional; (c) behavioral; dan atau (d) personality. Untuk mengidentifikasi masalah siswa, Prayitno dkk. telah 
mengembangkan suatu instrumen untuk melacak masalah siswa, dengan apa yang disebut Alat Ungkap Masalah (AUM). Instrumen ini sangat membantu untuk mendeteksi lokasi kesulitan yang dihadapi siswa, seputar aspek : (a) jasmani dan kesehatan; (b) diri pribadi; (c) hubungan sosial; (d) ekonomi dan keuangan; (e) karier dan pekerjaan; (f) pendidikan dan pelajaran; (g) agama, nilai dan moral; (h) hubungan muda-mudi; (i) keadaan dan hubungan keluarga; dan (j) waktu senggang.

\section{Diagnosis}

Diagnosis merupakan upaya untuk menemukan faktor-faktor penyebab atau yang melatarbelakangi timbulnya masalah siswa. Dalam konteks Proses Belajar Mengajar faktor-faktor yang menjadi penyebab kegagalan belajar siswa, bisa dilihat dari segi input, proses, ataupun output belajarnya. W.H. Burton membagi ke dalam dua bagian faktor-faktor yang mungkin dapat menimbulkan kesulitan atau kegagalan belajar siswa, yaitu: (a) faktor internal; faktor yang besumber dari dalam diri siswa itu sendiri, seperti: kondisi jasmani dan kesehatan, kecerdasan, bakat, kepribadian, emosi, sikap serta kondisi-kondisi psikis lainnya; dan (b) faktor eksternal, seperti: lingkungan rumah, lingkungan sekolah termasuk didalamnya faktor guru dan lingkungan sosial dan sejenisnya.

\section{Prognosis}

Langkah ini untuk memperkirakan apakah masalah yang dialami siswa masih mungkin untuk diatasi serta menentukan berbagai alternatif pemecahannya. Hal ini dilakukan dengan cara mengintegrasikan dan menginterpretasikan hasil-hasil langkah kedua dan ketiga. Proses mengambil keputusan pada tahap ini seyogyanya terlebih dahulu dilaksanakan konferensi kasus, dengan melibatkan pihak-pihak yang berkompeten untuk diminta bekerja sama menangani kasus-kasus yang dihadapi.

\section{Remedial atau Referal (Alih Tangan Kasus)}

Jika jenis dan sifat serta sumber permasalahannya masih berkaitan dengan sistem pembelajaran dan masih masih berada dalam kesanggupan dan kemampuan guru atau guru pembimbing, pemberian bantuan bimbingan dapat dilakukan oleh guru atau guru pembimbing itu sendiri. Namun, jika permasalahannya menyangkut aspek-aspek kepribadian yang lebih mendalam dan lebih luas maka selayaknya tugas guru atau guru pembimbing sebatas hanya membuat rekomendasi kepada ahli yang lebih kompeten. 


\section{Evaluasi dan Follow Up}

Cara manapun yang ditempuh, evaluasi atas usaha pemecahan masalah seyogyanya dilakukan evaluasi dan tindak lanjut, untuk melihat seberapa pengaruh tindakan bantuan (treatment) yang telah diberikan terhadap pemecahan masalah yang dihadapi siswa. Berkenaan dengan evaluasi bimbingan, Depdiknas telah memberikan kriteria-kriteria keberhasilan layanan bimbingan belajar, yaitu:

- Berkembangnya pemahaman baru yang diperoleh siswa berkaitan dengan masalah yang dibahas;

- Perasaan positif sebagai dampak dari proses dan materi yang dibawakan melalui layanan, dan

- Rencana kegiatan yang akan dilaksanakan oleh siswa sesudah pelaksanaan layanan dalam rangka mewujudkan upaya lebih lanjut pengentasan masalah yang dialaminya.

Sementara itu, Robinson mengemukakan beberapa kriteria dari keberhasilan dan efektivitas layanan yang telah diberikan, yaitu apabila:

- Siswa telah menyadari (to be aware of) atas adanya masalah yang dihadapi.

- Siswa telah memahami (self insight) permasalahan yang dihadapi.

- Siswa telah mulai menunjukkan kesediaan untuk menerima kenyataan diri dan masalahnya secara obyektif (self acceptance).

- Siswa telah menurun ketegangan emosinya (emotion stress release).

- Siswa telah menurun penentangan terhadap lingkungannya.

- Siswa mulai menunjukkan kemampuannya dalam mempertimbangkan, mengadakan pilihan dan mengambil keputusan secara sehat dan rasional.

- Siswa telah menunjukkan kemampuan melakukan usaha -usaha perbaikan dan penyesuaian diri terhadap lingkungannya, sesuai dengan dasar pertimbangan dan keputusan yang telah diambilnya. ${ }^{17}$

Beberapa metode mengatasi masalah kesulitan belajar di atas, memberikan alternatif pemecahan masalah. Dalam hal ini, metode pemecahan masalah tersebut sedikit berbeda walaupun pada dasarnya sama. Dengan demikian, tergantung kepada guru, orang tua untuk memilih sesuai dengan situasi dan kondisi yang ada.

\section{PENUTUP}

Pada dasarnya semua anak memiliki kemampuan, walaupun mungkin saja kemampuan yang dimiliki berbeda satu dengan yang lainnya. Pada tingkat pendidikan dasar berbagai kemampuan tersebut masih 
memiliki relasi yang kuat, membaca, menulis, serta berhitung. Masalah yang mungkin ada pada pada salah satu kemampuan tersebut dapat menggangu kemampuan yang lain. Dengan demikian, apa yang sering dilakukan baik sebagai orang tua ataupun seorang guru dengan mengatakan seorang anak yang mendapatkan nilai yang rendah merupakan anak yang bodoh dan gagal perlu menjadi perhatian. Sebab, sebagaimana diketahui bahwa mungkin saja anak hanya mengalami gangguan pada salah satu kemampuan tadi, dan ia tidak tahu bagaimana mengatasi masalah tersebut.

Untuk itu, yang terpenting adalah dapat menelaah dengan baik perkembangan anak. Diagnosis terhadap permasalahan sesungguhnya yang dialami anak mutlak harus dilakukan. Dengan demikian kita akan mengetahui kesulitan belajar apa yang dialami anak, sehingga kita dapat menentukan alternatif pilihan bantuan bagaimana mengatasi kesulitan tersebut.

\section{CATATAN AKHIR:}

1. Sudrajat, Akhmad, akhmadsudrajat.wordpress.com, 2009, h. 2

2. http://www.kesulitanbelajar.org, h. 1

3. Sudrajat, Akhmad, akhmadsudrajat.wordpress.com, h. 1

4. Syah, Muhibbin, Psikologi Pendidikan, Bandung, PT. Remaja Rosda Karya, 2000, h. 173-174.

5. Syah, Muhibbin, Psikologi Pendidikan, Bandung, h. 174.

6. Sternberg, Robert, Penerjemah Yudi Santoso, Psikologi Kognitif, Yogyakarta, Pustaka Pelajar, 2008, h. 28.

7. Sternberg, Robert, Penerjemah Yudi Santoso, h. 52-53.

8. Ahmadi, Abu \& Supriyono Widodo, Psikologi Belajar, Jakarta, Rineka Cipta, 2004, h. 5-7.

9. Sudrajat, Akhmad, akhmadsudrajat.wordpress.com, h. 2

10. Syamsuddin, Abin, Psikologi Pendidikan, Bandung, PT Remaja Rosda Karya, 2003.

11. http//www.kesulitanbelajar.org

12. Syah, Muhibbin, Psikologi Pendidikan, h. 174.

13. Syah, Muhibbin, Psikologi Pendidikan, h. 175.

14. Wood, Derek et al, Penerjemah Taniputra, Kiat Mengatasi Gangguan Belajar, Yogyakarta, Kata Hati, 2005.

15. Sudrajat, Akhmad, akhmadsudrajat.wordpress.com, h. 6-7

16. Syamsuddin, Abin, Psikologi Pendidikan, 2003.

17. Syamsuddin, Abin, Psikologi Pendidikan, 2003. 


\section{DAFTAR PUSTAKA}

Ahmadi, Abu \& Supriyono Widodo, Psikologi Belajar, Jakarta, Rineka Cipta, 2004.

Feldmen, William, Penerjemah Sudarmaji, Mengatasi Gangguan Belajar Pada Anak. Jakarta, Prestasi Putra, 2002.

Prayitno dan Erman Anti, Dasar-Dasar Bimbingan dan Konseling, Jakarta, P2LPTK Depdikbud, 1995.

Prayitno, Panduan Bimbingan dan Konseling, Jakarta, Depdikbud Direktorat Pendidikan Dasar dan Menengah, 2003.

Sternberg, Robert, Penerjemah Yudi Santoso, Psikologi Kognitif, Yogyakarta, Pustaka Pelajar, 2008.

Sudrajat, Akhmad, akhmadsudrajat.wordpress.com/kesulitan-dan-bimbingan-belajar/ Syah, Muhibbin, Psikologi Pendidikan, Bandung, PT. Remaja Rosda Karya, 2000. Syamsuddin, Abin, Psikologi Pendidikan, Bandung, PT Remaja Rosda Karya, 2003. Winkel, W.S., Bimbingan dan Konseling di Institusi Pendidikan, Jakarta, Gramedia, 1991.

Wood, Derek et al, Penerjemah Taniputra, Kiat Mengatasi Gangguan Belajar, Yogyakarta, Kata Hati, 2005.

http//www.kesulitanbelajar.org 